\title{
STUDY OF RUNNING ENGINES INERTIAL AND GYROSCOPIC PROPERTIES INFLUENCE ON THE DYNAMIC SYSTEM ENGINE - PYLON - WING STRUCTURAL CAPABILITIES
}

\author{
V.V. OVCHINNIKOV ${ }^{1}$, YU.V. PETROV ${ }^{2}$ \\ ${ }^{1}$ Bauman Moscow State Technical University, Moscow, Russia \\ ${ }^{2}$ The Moscow State Technical University of Civil Aviation, Moscow, Russia
}

\begin{abstract}
A modern large-sized aircraft dynamic properties analysis, determined by the specificity of its layout scheme, demonstrates that the engines on under the wing elastic pylons lightly damped oscillations cause a number of undesirable phenomena, including intense accumulation of fatigue damage of the pylon-to-the-wing attachment, in fact in the area of engine installation in the pylon and the wing. The results of theoretical and experimental research show that with some engine attachment to the pylon structural modification it becomes possible to use the engines inertial and gyroscopic properties to absorb these oscillations. In this case, the motor tones damping coefficients increase by an order of magnitude or even more, so the gyroscopic coupling of elastic vibration tones is realized. With the rational choice of the additional parameters of elastic and dissipative bonds in the engine attachments it is possible to affect the aircraft wing and engines aero elastic vibrations effectively, which has a significant effect on the aircraft elements structural capabilities. A mathematical model of aero elasticity (MMAE) with respect to the kinetic moment of the engine rotors and specially designed units for attaching the engines to the pylons was developed in order to study the influence and the selection of rational elastic-dissipative parameters of the pylons-under-the-wing aircraft engine mounts. The method of predetermined basic forms is used for the aircraft with running engines on the pylons MMAE synthesis. The given forms are considered as the aircraft basic structure forms natural vibrations in the void. This work treats the engine nacelle and the rotor as absolutely rigid bodies, the elasticity of the rotor to the nacelle attachment is neglected. The pylon is modeled by an elastic beam, and the elastic and dissipative properties of the pylon-to-the-wing and the engine-to-the-pylon attachments are correspondingly by elastic-dissipative bonds. Schematic diagrams of the engine to the pylon attachments are proposed. The results of the study devoted to the influence of the proposed attachment points modifications on the load and integral strength characteristics of the main structural elements of the engine - pylon - wing dynamic system on the example of an An-124 aircraft are presented. The practical implementation of the proposed solutions aimed to reduce the level of fatigue damage to structural elements of the aircraft feasibility is proved.
\end{abstract}

Key words: aero elasticity, pylon engine, inertial and gyroscopic properties, elastic-dissipative bonds, fatigue damage, resource.

\section{INTRODUCTION}

One of the main features of a modern aircraft layout is the location of engines on elastic pylons under the wing. With obvious design and operational advantages of such a layout, an actual problem arises: engines on elastic pylons lightly damped oscillations. This phenomenon is conditioned by the fact that the oscillations energy dissipation in the dynamic engine - pylon - wing system is only performed by internal and structural damping. Engines on elastic pylons oscillations lead to the elements of the wing and pylon structure fatigue damage accumulation and to the aero elastic dynamic instability of the "pylon" flutter type occurrence as well as to the worsen the crew and equipment operation performance.

At the same time, the results of theoretical and experimental studies [1-9] show that certain engine to pylons attachment points design modifications, aimed at some engine and pylon relative displacement provision, can significantly increase the dissipative properties of the engine - pylon - wing dynamic system. In this case, special elastic elements and damping devices are introduced into the structure, and the running engine can be used as an inertial and gyroscopic oscillations dampener [10-15]. Research shows that with rational (tuning) values of the engine to the pylon attachment elastic dissipative parameters, it is possible to influence the aero elastic oscillations of the engine - py- 
lon - wing dynamic system effectively. At the same time, the damping coefficients of motor tones increase by an order of magnitude or more.

This paper studies some design schemes of engine to pylon attachment points and the influence of the proposed modifications on the aero elastic oscillations in the engine - pylon - wing dynamic system is analyzed. Mathematical model of an aircraft with operative elastic pylons engines, which is developed by the authors, is used for analytical research [1]. The results of the study devoted to the influence of the proposed attachment points modifications on the load and integral strength characteristics of the main structural elements of the engine - pylon - wing dynamic system on the example of an An-124 aircraft are presented. The practical implementation of the proposed solutions aimed to reduce the level of fatigue damage to structural elements of the aircraft feasibility is proved.

\section{MATHEMATICAL MODEL OF THE AIRCRAFT AERO ELASTICITY WITH THE ENGINES RUNNING ON ELASTIC PYLONS}

The development of a mathematical model of aero elasticity (MMAE) is an important stage in the study of the engine attachment points to elastic pylons under-the-wing structural modifications influence on the aircraft structural elements strength characteristics. The method of predetermined basic forms is used for the aircraft with running engines on the pylons MMAE synthesis [1, 16-20]. In accordance with this method, the deformations of structures in perturbed motion take the form of expansion in a series of known coordinate vector functions (forms). The given forms are considered to be the forms of the aircraft basic structure natural oscillations in the void. This work treats the engine nacelle and the rotor as absolutely rigid bodies, the elasticity of the rotor to the nacelle attachment is neglected. The pylon is modeled by an elastic beam, and the elastic and dissipative properties of the pylon-to-the-wing and the engine-to-the-pylon attachments are correspondingly by elasticdissipative bonds. The engine has a kinetic moment $\boldsymbol{H}_{\boldsymbol{P}}$ the influence of the engine thrust dynamic components is neglected. Thus, in [3] it is shown that the influence of dynamic thrust components on the natural frequencies and forms of oscillations, as well as on the flutter characteristics of the aircraft, is insignificant and can be ignored. When calculating aerodynamic characteristics, the engine is schematized as a set of vertical and horizontal thin bearing surfaces modeled by a family of attached and free vortices.

We consider an elastic plane that performs a steady horizontal flight at the speed of $V_{\infty}$ in its initial state. Having the set-up inertia-mass engine parameters, the pylon geometric characteristics, the rotor kinetic moment $\boldsymbol{H}_{\boldsymbol{P}}$, the engine-to-the-pylon attachment points elastic-dissipative parameters, using the Lagrange equations, it is possible to form a perturbed motion equation of an elastic aircraft with the engine running on the pylon as shown in [1]. In the matrix form the mathematical model of an aircraft aero elasticity (MMAE) has the following form:

$$
\begin{aligned}
& {\left[M_{B D}\right]\left\{\ddot{q}_{B D}\right\}+\left[D_{B D}\right]\left\{\dot{q}_{B D}\right\}+\left[B_{B D}\right]\left\{q_{B D}\right\}=\left[P_{H}\right],} \\
& \left\{q_{B D}\right\}=\|\left\{\begin{array}{l}
\left\{q_{\mathrm{B}}\right\} \\
\left\{q_{d}\right\}
\end{array}\left\|, \quad\left[M_{B D}\right]=\right\| \begin{array}{cc}
{\left[M_{B}\right]} & {[0]} \\
{[0]} & {[0]}
\end{array}\left\|, \quad\left[B_{B D}\right]=\right\| \begin{array}{cc}
{\left[B_{B}\right]} & {[0]} \\
{[0]} & {\left[B_{d}\right] \|,}
\end{array} \|,\right. \\
& {\left[D_{B D}\right]=\left[D_{B}\right]+\left[D_{d}\right]+\left[G_{B G}\right], \quad\left[B_{d}\right]=\left[F_{d}\right]^{T}\left[B_{d}^{0}\right]\left[F_{d}\right] \text {, }} \\
& {\left[B_{d}^{0}\right]=\operatorname{diag}\left[b_{d 1}, \ldots, b_{d j}, \ldots, b_{d 6}\right] \text {, }}
\end{aligned}
$$




$$
\begin{aligned}
& {\left[D_{d}\right]=\left[F_{d}\right]^{T}\left[D_{d}^{0}\right]\left[F_{d}\right], \quad\left[D_{d}^{0}\right]=\operatorname{diag}\left[d_{d 1}, \ldots, d_{d j}, \ldots, d_{d 6}\right],}
\end{aligned}
$$

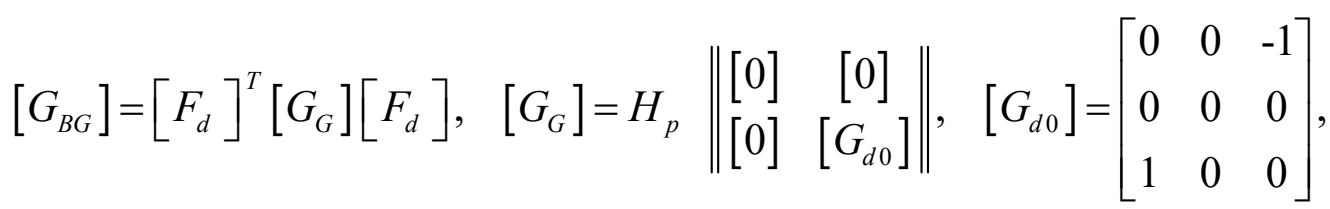

where $\left[M_{B}\right],\left[D_{B}\right],\left[B_{B}\right]$ are correspondingly the generalized mass, damping, and stiffness of the base model matrix;

$\left\{q_{\mathrm{B}}\right\}$ - is the vector - a column of generalized coordinates describing the relative engine and pylon due to the flexibility of the attachment points displacement;

$\left\{q_{d}\right\}$ - is the vector - a column of generalized coordinates describing the relative engine and pylon due to the malleability of the attachment points displacements;

$\left[D_{d}\right],\left[B_{d}\right]$ - are damping and elasticity matrixes of the additional elastic dissipative bonds;

$\left[G_{B G}\right]$ - is the influence of the running engine (gyroscopic coupling by generalized coordinates) matrix;

$\left[F_{d}\right]$ - is the matrix, made up of vectors projections of absolute linear and angular displacements associated with the coordinate system engine on the corresponding axes of this system;

$\left[P_{H}\right]$ - is the matrix of generalized external forces;

$[0]$ - is the null matrix.

Let's assume that all basic structure parameters are known, and the matrix of internal and structural damping coefficients is set.

Let the coordinate system $O x_{1} x_{2} x_{3}$ be connected to the engine (Fig. 1).

The following designations in Figure 1 and Figure 2 are used: 1 - beam model of the wing console; 2 - beam model of the pylon; 3 - engine; 4 - additionally introduced elastic elements of the engine attachment points to the pylon design; 5 - additionally introduced dissipative elements of the engine attachment points to the pylon design (for example, hydraulic dampers). The engine generally has six degrees of freedom of relative displacements, which are set by the vector $\left\{q_{d}\right\}$. At the same time $q_{d 1}, q_{d 2}, q_{d 3}$ are - the coordinates describing the engine linear displacement due to its attachment points to the pylon malleability; $q_{d 4}, q_{d 5}, q_{d 6}$ are - the coordinates of relative angular deviation; $b_{d k}, d_{d k}(k=\overline{1,6})$ - is the partial coefficients of stiffness and damping of the corresponding elastic and dissipative elements.

The research has shown that the maximum effect of damping the motor tones vibrations with minimal modifications of the original engine to the pylon attachment scheme is achieved by ensuring that it can rotate about the axis $O x_{1}$ (fig.1, coordinate $q_{d 4}$ ) or the axis $a-a$ (fig. 2, coordinate $q_{d 5}$ ). In the first case, the provisionally released engine is a gyroscopic oscillation damper, built according to the scheme of a high - speed gyroscope, and in the second case it is a damper of inertial oscillations with friction. 


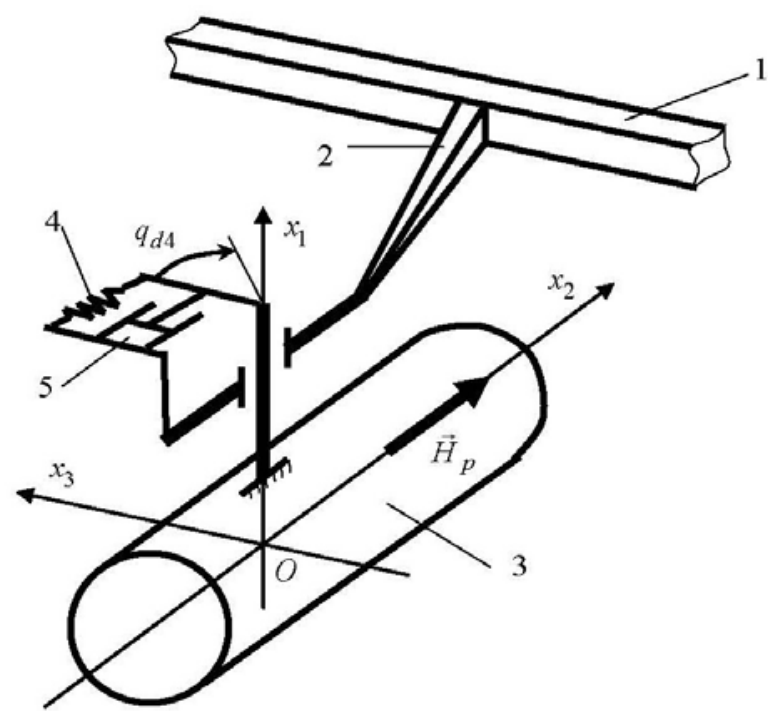

Fig. 1. The engine-to-the-pylon fastening scheme with the possibility of rotation around the $O x_{1}$ axis

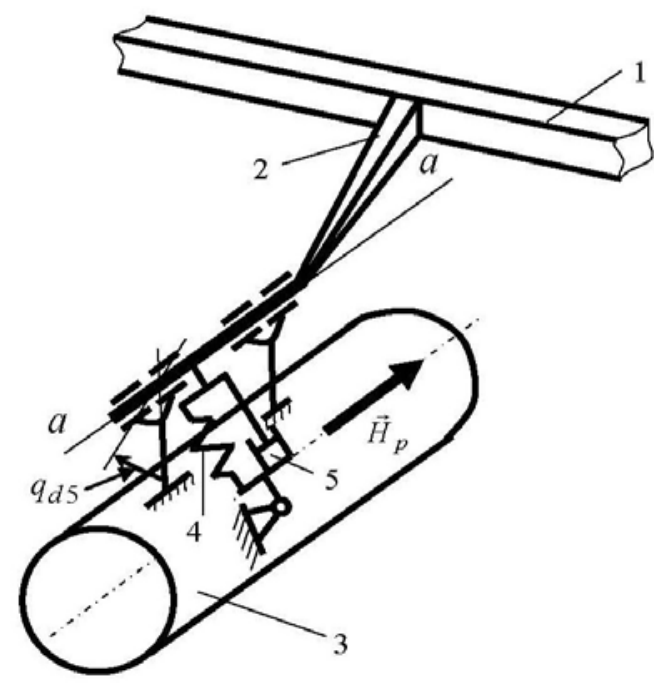

Fig. 2. The engine-to-the-pylon fastening scheme with the possibility of rotation around the $a-a$ axis

\section{RESEARCH RESULTS OF THE RUNNING ENGINES INFLUENCE ON THE AIRCRAFT STRUCTURAL CAPABILITIES}

The aircraft with modified engine attachment points aero elastic and structural capabilities mathematical modeling process consisted of two stages. At the first stage, the rational (set-up) elasticdissipative parameters of the engine attachment points to the pylons for a given suspension variant were determined (fig. 1 or fig. 2). The mathematical model of aero elasticity created in accordance with the method of specified basic forms was used. The system of equations was solved with the use of own values for different damping and stiffness coefficients of additional elastic-dissipative elements, while the partial compliance with other generalized coordinates corresponded to the initial values of the base model. As set-up parameters of a suspension bracket such parameters were accepted at which damping coefficients (the real part of the characteristic equation roots) of the motor tones reached the maximum values on absolute size. The second stage, studied the influence of the engine with modified 
attachment points on the aero elastic and structural capabilities of the aircraft. Some calculation results are shown in Figures 3 ... 7.

Dynamic reaction of the large-sized plane of the An-124 type to external disturbance and control influences was investigated in particular. The analysis of the obtained data shows that the engine with modified attachment points has a significant impact on the intensity and repeatability of dynamic loads acting on the pylon and wing of the aircraft. Thus, Figure 3 shows the normalized oscillogram of the bending moment increments in the root section of the external engine pylon $\Delta \bar{M}_{x}^{p}$ with the following initial data: the aircraft's flight speed $V_{\infty}=100 \mathrm{~m} / \mathrm{s}$; the vertical gust speed $W_{y}=10 \mathrm{~m} / \mathrm{s}$; the aircraft without fuel. A solid line shows the dependence at the original engine mounting scheme, a dashed line shows the dependence at the set-up parameters of the conditionally released engine relative to the vertical axis (fig. 1). The similar oscillogram for increase of the bending moment $\Delta \bar{M}_{x}^{k}$ in the section of the wing corresponding to the external engine mounting location is shown in Figure 4.

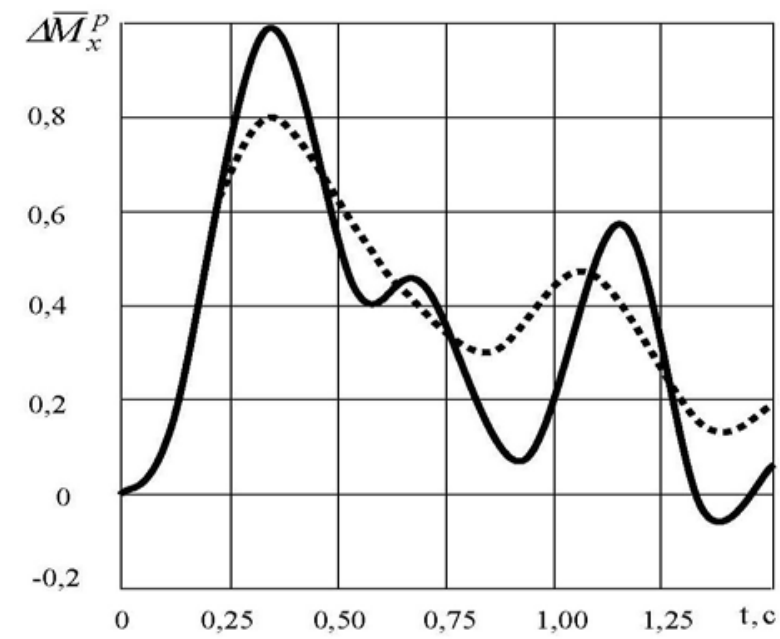

Fig. 3. Normalized oscillogram of bending moment increase in the root section of the external engine pylon

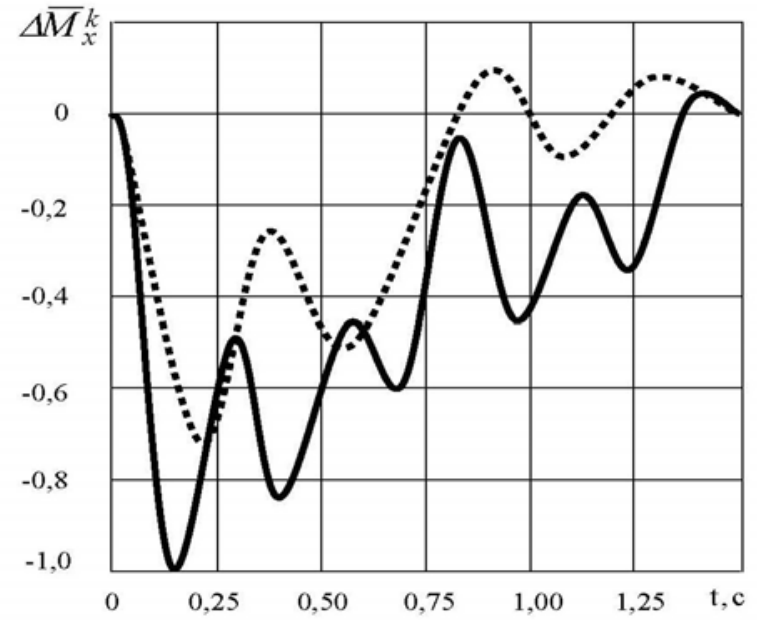

Fig. 4. Normalized oscillogram of bending moment increase in the wing section corresponding to the external engine mounts location

The rational choice of the engine suspension elastic-dissipative parameters allows you to reduce significantly the amplitude of its oscillations, primarily in the area of torsion and engine elastic tones. As an example, Figure 5 shows normalized amplitude-frequency response characteristic (AFC) of the vertical oscillations $\bar{A}_{y}$ in the center of mass of the external engine in the An-124 aircraft without fuel in the area of torsion and motor elastic tones. The elastic tones on the frequency axis are arranged in the following sequence: symmetrical torsion oscillations of the wing first tone SK1; the engine vertical oscillations SDV; the engine lateral oscillations SB; symmetrical torsion oscillations of the second tone wing SK2; symmetrical horizontal bending oscillations $f$ the first tone wing SGI1; symmetrical bending oscillations of the first tone fuselage SIFL. The solid line corresponds to the original parameters of the suspension, the dashed line corresponds to the engine, conditionally released related to the horizontal axis $a-a$ (fig. 2). It is evident that the amplitude-frequency characteristic of the engine vertical and lateral oscillations changes significantly in the lower elastic torsion vibration tones of the wing. Due to the gyroscopic coupling of the wing and the engine elastic vibration tones, both the natural frequencies absolute values and the engine - pylon - wing dynamic system dissipative 
properties change. The external engine oscillation wide frequency range amplitudes are reduced by $1.5 \ldots 5$ times.

It is obvious that decrease in level and repeatability of the dynamic loads which effects the engine - pylon - wing system leads to the reduction of fatigue damageability of the design elements and to the increase of their resource. An important quantitative characteristic of the aircraft structure loading capacity is the spectral density of the bending moment in the calculated cross sections.

Figure 6 shows the normalized spectral density of the bending moment $\bar{S}_{M}^{K}$ in the An-124 aircraft wing section, corresponding to the attachment point of the external engine, when the aircraft is taxiing along the airfield without fuel at the speed of $=10 \mathrm{~m} / \mathrm{s}$. The solid line shows the curve for the original engine mounting scheme, and a dashed line for the mounting scheme shown in Figure 2.

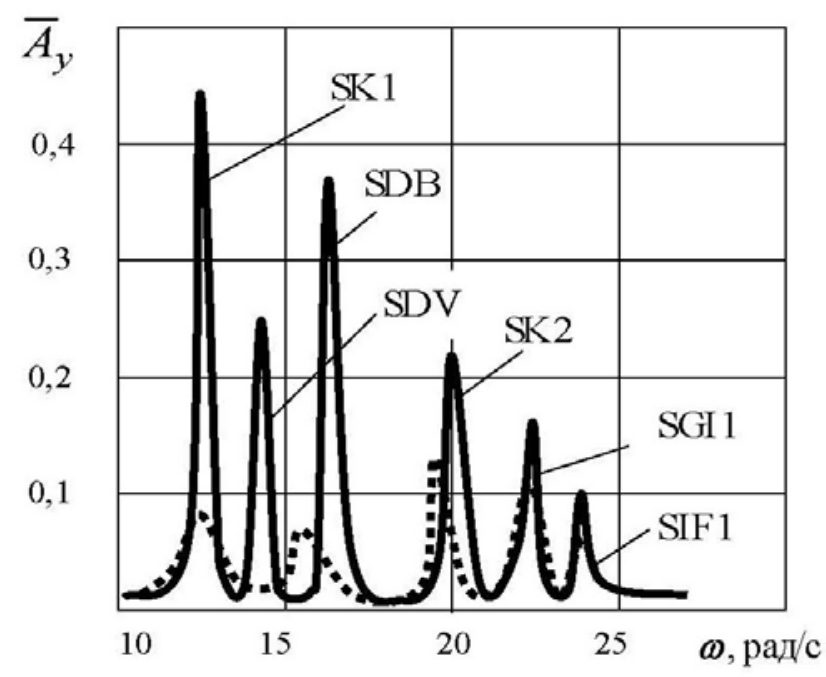

Fig. 5. Normalized amplitude-frequency characteristic of the An-124 aircraft external engine center of mass vertical oscillations $\bar{A}_{y}$

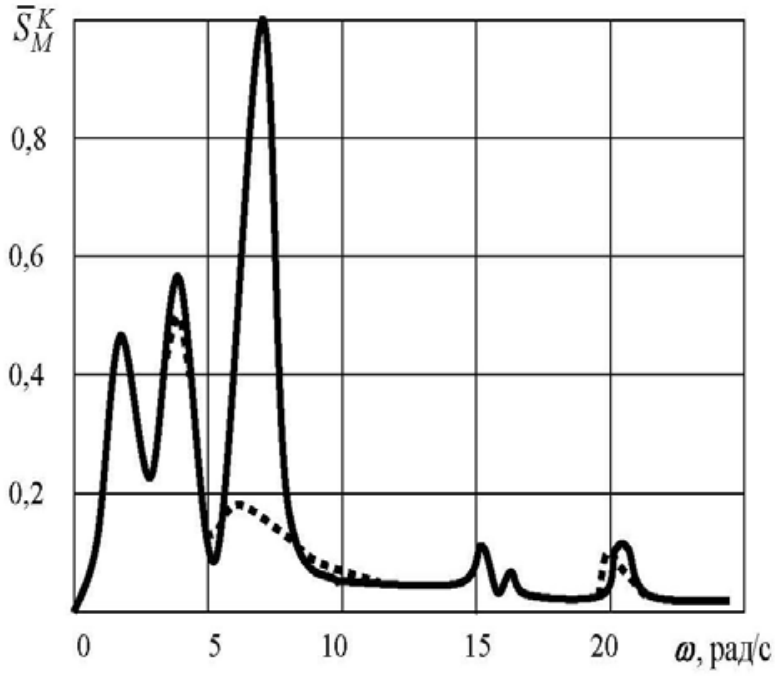

Fig. 6. Normalized spectral density of the An-124 aircraft wing section bending moment, corresponding to the attachment point of the external engine

The obtained spectral characteristics of changes in the integral force factors in the cross sections of the aircraft structure elements were used to quantify the resource in accordance with the hypothesis of spectral summation of fatigue damage. In particular, some impact assessment results of the proposed improvements of the engine-to-the-pylon attachment points, strength characteristics of the large An-124 type aircraft main structural wing elements are shown in Figure 7 in the form of the graphs showing the resource increase coefficient changes for the lower $\bar{T}_{N}$ and upper $\bar{T}_{V}$ panels at the external engine attachment point.

The figures demonstrate $\bar{l}=l_{x 1} / l_{x 2} ; l_{x 1}$ - is the engine center of mass removal down relatively to the pylon attachment points (along the $\mathrm{O} x_{1}$ axis in Fig. 1 ); $l_{x 2}$ - is the engine center of mass removal forward along the $O x_{2}$ axis. 

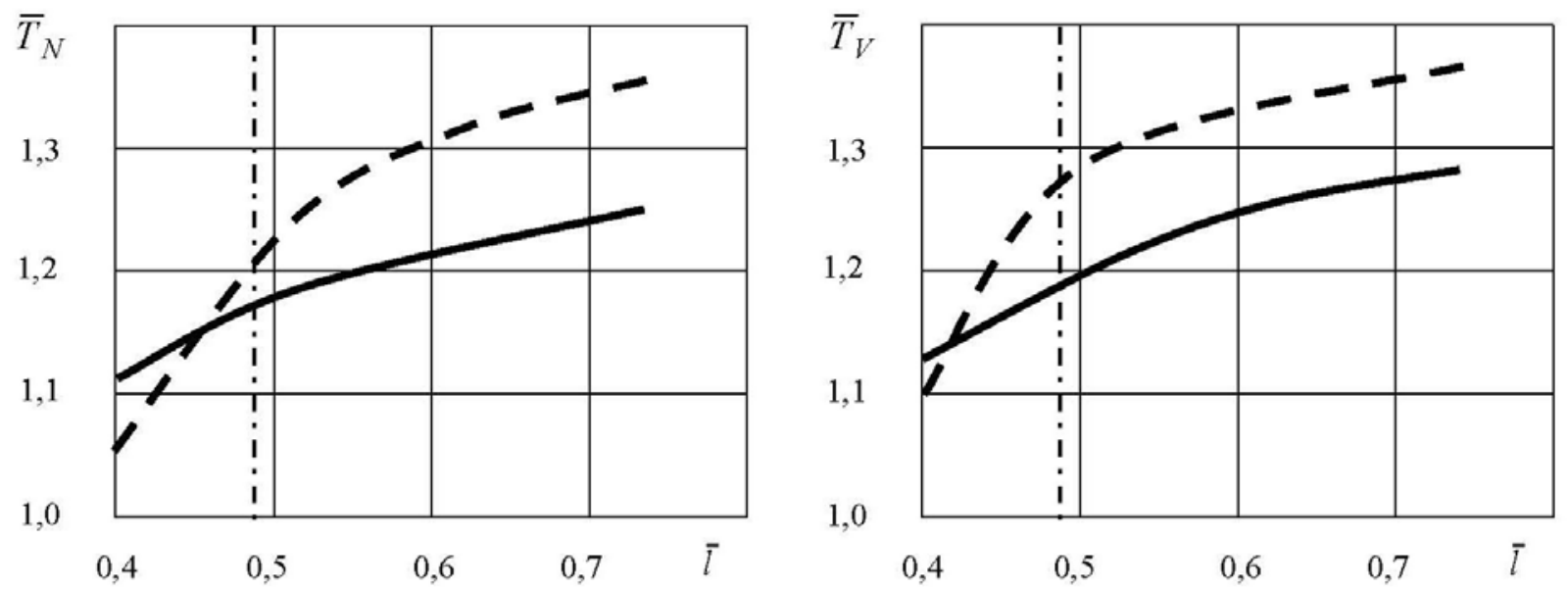

Fig. 7. The graph of the resource-increase coefficient changes for the wing lower $\bar{T}_{N}$ and upper $\bar{T}_{V}$ panels of the An-124 aircraft at the external engine attachment point

The solid line shows the released engine dependence relatively the vertical axis (diagram fig. 1), the dashed line shows the released engine dependence relatively the horizontal axis (diagram fig. 2). The dashed line corresponds to the $\bar{l}$ value of the production An-124 aircraft. All the mentioned above data are obtained with taking into account the engine rotor kinetic moment influence.

\section{CONCLUSION AND DISCUSSION OF THE OBTAINED RESULTS}

We studied the influence of elastic and dissipative parameters of engine attachment points on the elements of the engine - pylon - wing dynamic system strength characteristics using the mathematical model of aero elasticity developed by the authors, which takes into account the kinetic moment of engine rotors. Potential attachments structural modifications which make it possible to have the greatest impact on the intensity and repeatability of loads on the structure are proposed. As an example, the results of the An-124 aircraft wing elements resource evaluation in accordance with the spectral summation of fatigue damage hypothesis are presented. It is shown that the specially designed elastic and damping elements being introduced into the structure allow us to expect the resource of individual structural elements increase by up to $30 \%$.

\section{REFERENCES}

1. Ovchinnikov, V.V. and Petrov, Iu.V. (2017). Chislennyye metody issledovaniya aerouprugosti letatelnykh apparatov: Monografiya [Numerical methods for the study of aircraft aeroelasticity: a monography]. Moscow: Izdatelskiy dom Academii imeni N.E. Zhukovskogo, 160 p. (in Russia)

2. Fujino, M., Oyama, H. and Omotani, H. (2003). Flutter characteristics of an over-thewing engine mount business-jet configuration. $44^{\text {th }}$ AIAA/ASME/ASCE/AHS Structures, Structural Dynamics and Materials Conference. AIAA 2003-1942, pp. 1-12. DOI: 10.2514/6.2003-1942

3. Waitz, S. and Hennings, H. (2015). The aeroelastic impact of engine thrust and gyroscopics on aircraft flutter instabilities. International Forum on Aeroelasticity and Structural Dynamics, IFASD-2015, pp. 1-15.

4. Skelly, J. and Laporte, A. (2011). Engine pylon for aircraft. Patent US, no. US20110204179A1, August 25, 2011, 7 pp.

5. Wang, L., Wan, Z., Wu, Q. and Yang, Ch. (2012). Aeroelastic modeling and analysis of the wing/engine system of a large aircraft. Procedia Engineering, vol. 31, pp. 779-885. DOI: https://doi.org/10.1016/j.proeng.2012.01.1116 
6. Liu, D., Wan, Z., Yang, Ch. and Yang, T. (2010). Primary modeling and analysis of wing based on aeroelastic optimization. AIAA/ASME/ASCE/AHS/ASC Structures, Structural Dynamics and Materials Conference. AIAA 2010-2719, 15 p. DOI: https://doi.org/10.2514/6.2010-2719

7. Barys, M. and Zalewski, R. (2018). Analysis of inertial amplification mechanism with smart spring-damper for attenuation of beam vibrations. MATEC Web of Conferences: Machine Modelling and Simulations, vol. 157, 03002, 9 pp. DOI: https://doi.org/10.1051/matecconf/201815703002

8. Kumar, G., Walter, E. and Jack, S. (1991). Vibration damping aircraft engine attachment. Patent US, no. US5065959A, November 19, 1991, 8 p.

9. Haber, O. (2006). Vibration damping pylon. Patent US, no. US20060060713A1, March 23, 2006, 9 p.

10. Frolov, K.V. (Ed.). (1981). Vibratsiya v tekhnike: spravochnik $v$ 6-ti tomakh [Vibration in technology: guide in 6 volumes]. Tom 6 Zashchita ot vibratsii i udarov [Vibration and shock protection, vol 6]. Moscow: Mashinostroyeniye, 456 p. (in Russian)

11. Serov, M.V., Averyanov, G.M. and Alexandrova, S.G. (2013). Experience of using vibration theory to practical issues of application of inertial dynamic vibration absorbers. Scientific journal "Izvestiya MGTU "MAMI", vol. 3, no. 1 (15), pp. 118-124. (in Russian)

12. He, H., Xie, X. and Wang, W. (2017). Vibration control of tower structure with multiple cardan gyroscope. Shock and Vibration, vol. 2017, article ID 3548360, 11 pp. DOI: https://doi.org/10.1155/2017/3548360

13. Nashif, A.D., Jones, D.I.G. and Henderson, J.P. (1985). Vibration Damping. John Wiley \& Sons, $480 \mathrm{p}$.

14. De Silva, C.W. (2007). Vibration damping, control, and design. 1st ed., CRC Press, 634 p.

15. Ünker, F. and Çuvalci, O. (2015). Vibration control of a column using a gyroscope. Procedia - Social and Behavioral Sciences, vol. 195, 3 July, pp. 2306-2315. DOI: $10.1016 /$ j.sbspro.2015.06.182

16. William, P.R. (2011). Theoretical and computational aeroelasticity. 1st ed., Crest Publishing, $347 \mathrm{p}$.

17. Chernyshev, S.L., Zichenkov, M.Ch., Ishmuratov, F.Z. and Chedrik, V.V. (2017). Tendencies in development of computational mechanics for strength design of aircraft structures. Chebyshevskii Sbornik, vol. 18, no. 3 (63), pp. 488-505. DOI: 10.22405/2226-8383-2017-18-3-488-505

18. Parafes, S.G. and Smyslov, V.I. (2018). Proektirovaniye konstruktsii $i$ SAU BPLA s uchetom aerouprugosti. Postanovka $i$ metody resheniya zadach [Design of the structure and selfpropelled guns of UAVs taking into account aeroelasticity. Statement and methods of solving the problem]. Moscow: Izdatelstvo Tekhnosfera, 182 p. (in Russia)

19. Garifullin, M.F. (2016). Chislitelnyye metody $v$ raschetnykh i eksperimentalnykh issledovaniyakh nestatsionarnykh yavleniy aerouprugosti. Kniga 1: Chislennyye metody v raschetnykh issledovaniyakh [Numerical methods in the calculation and experimental studies of unsteady phenomena of aeroelasticity. Book 1. Numerical methods in computational research] Moscow: Nauka, 350 p. (in Russian)

20. Wright, J.R. and Cooper, J.E. (2015). Introduction to Aircraft Aeroelasticity and Loads. 2nd ed., John Wiley \& Sons, 574 p.

\section{INFORMATION ABOUT AUTHORS}

Valery V. Ovchinnikov, Doctor of Technical Sciences, Professor, the Head of Physics Fundamentals Chair, Bauman Moscow State Technical University, Moscow, Russia, vvovchinnikov@bk.ru.

Yuriy V. Petrov, Doctor of Technical Sciences, Professor, the Head of Technical Mechanics and Engineering Graphics Chair, Moscow State Technical University of Civil Aviation, Moscow, Russia, doctor561@rambler.ru. 


\title{
ИССЛЕДОВАНИЕ ВЛИЯНИЯ ИНЕРЦИОННЫХ И ГИРОСКОПИЧЕСКИХ СВОЙСТВ РАБОТАЮЩИХ ДВИГАТЕЛЕЙ НА ПРОЧНОСТНЫЕ ХАРАКТЕРИСТИКИ ДИНАМИЧЕСКОЙ СИСТЕМЫ ДВИГАТЕЛЬ - ПИЛОН - КРЫЛО
}

\author{
В.В. Овчинников ${ }^{1}$, Ю.В. Петров ${ }^{2}$ \\ ${ }^{1}$ Московский государственный технический университет имени Н.Э. Баумана, \\ 2. Москва, Россия \\ ${ }^{2}$ Московский государственный технический университет гражданской авиации, \\ г. Москва, Россия
}

\begin{abstract}
Анализ особенностей динамических свойств современного крупногабаритного самолета, обусловленных спецификой его компоновочной схемы, показывает, что слабодемпфированные колебания двигателей на упругих пилонах под крылом являются причиной ряда нежелательных явлений, в том числе интенсивного накопления усталостных повреждений узлов крепления двигателя к пилону, пилона к крылу, собственно в пилоне и крыле в месте установки двигателей. Результаты теоретических и экспериментальных исследований показывают, что при определенной доработке конструкции узлов крепления двигателя к пилону появляется возможность использовать инерционные и гироскопические свойства двигателей для гашения данных колебаний. В этом случае на порядок и более возрастают коэффициенты демпфирования двигательных тонов, реализуется гироскопическая связанность упругих тонов колебаний. При рациональном выборе параметров дополнительных упругих и диссипативных связей в узлах крепления двигателей удается достаточно эффективно воздействовать на аэроупругие колебания крыла самолета и двигателей, что оказывает существенное влияние на прочностные характеристики элементов конструкции ЛА. Для исследования влияния и выбора рациональных упругодиссипативных параметров подвески двигателей самолета на пилонах под крылом разработана математическая модель аэроупругости (ММАУ) с учетом кинетического момента роторов двигателей и специальным образом сконструированных узлов крепления двигателей к пилонам. Для синтеза ММАУ самолета с работающими двигателями на пилонах используется хорошо зарекомендовавший себя метод заданных базовых форм. В качестве заданных форм рассматриваются формы собственных колебаний базовой конструкции самолета в пустоте. В данной работе гондола и ротор двигателя рассматриваются как абсолютно жесткие тела, упругостью узлов крепления ротора к гондоле пренебрегается. Пилон моделируется упругой балкой, а упругие и диссипативные свойства узлов крепления пилона к крылу и двигателя к пилону соответствующими упругодиссипативными связями. Предложены принципиальные схемы узлов крепления двигателя к пилону. Приводятся результаты исследования влияния предлагаемых доработок узлов крепления на нагруженность и интегральные прочностные характеристики основных конструктивных элементов динамической системы двигатель - пилон - крыло на примере самолета Ан-124. Доказана целесообразность практической реализации предлагаемых решений для снижения уровня усталостной повреждаемости элементов конструкции самолета.
\end{abstract}

Ключевые слова: аэроупругость, двигатель на пилоне, инерционные и гироскопические свойства, упругодиссипативные связи, усталостная повреждаемость, ресурс.

\section{СПИСОК ЛИТЕРАТУРЫ}

1. Овчинников В.В., Петров Ю.В. Численные методы исследования аэроупругости летательных аппаратов: монография. М.: ИД Академии имени Н.Е. Жуковского, 2017. 160 с.

2. Fujino M., Oyama H., Omotani H. Flutter characteristics of an over-the-wing engine mount business-jet configuration $/ / 44^{\text {th }}$ AiAA/ASME/ASCE/AHS Structures, Structural Dynamics and Materials Conference. AIAA 2003-1942, 2003. Pp. 1-12. DOI: 10.2514/6.2003-1942

3. Waitz S., Hennings $\mathbf{H}$. The aeroelastic impact of engine thrust and gyroscopics on aircraft flutter instabilities // International Forum on Aeroelasticity and Structural Dynamics. IFASD-2015. Russia, Saint Petersburg, 2015. Pp. 1-15.

4. Skelly J., Laporte A. Engine pylon for aircraft. Patent US. No. US20110204179A1, 25.08.2011. 7 p.

5. Wang L. Aeroelastic modeling and analysis of the wing/engine system of a large aircraft / L. Wang, Z. Wan, Q. Wu, Ch. Yang // Procedia Engineering. 2012. Vol. 31. Pp. 879-885. DOI: https://doi.org/10.1016/j.proeng.2012.01.1116 
6. Liu D. Primary modeling and analysis of wing based on aeroelastic optimization / D. Liu, Z. Wan, Ch. Yang, T. Yang // AIAA/ASME/ASCE/AHS/ASC Structures, Structural Dynamics and Materials Conference. AIAA 2010-2719, 2010. 15 p. DOI: https://doi.org/10.2514/6.2010-2719

7. Barys M., Zalewski R. Analysis of inertial amplification mechanism with smart springdamper for attenuation of beam vibrations [Электронный pecypc] // MATEC Web of Conferences: Machine Modelling and Simulations. 2018. Vol. 157. 03002. 9 pp. DOI: https://doi.org/10.1051/ matecconf/201815703002 (дата обращения 01.02.2020).

8. Kumar G., Walter E., Jack S. Vibration damping aircraft engine attachment. Patent US. No. US5065959A, 19.11.1991. 8 p.

9. Haber O. Vibration damping pylon. Patent US. No. US20060060713A1, 23.03.2006. 9 p.

10. Вибрации в технике: справочник в 6-ти т. Т. 6. Защита от вибрации и ударов / Под ред. К.В. Фролова М.: Машиностроение, 1981. 456 с.

11. Серов М.В., Аверьянов Г.М., Александрова С.Г. Опыт применения теории колебаний к практическим вопросам применения инерционных динамических гасителей колебаний // Известия МГТУ «МАМИ». 2013. Т. 3, № 1 (15). С. 118-124.

12. He H., Xie X., Wang W. Vibration control of tower structure with multiple cardan gyroscope // Shock and Vibration. 2017. Vol. 2017. Article ID 3548360. 11 pp. DOI: https://doi.org/10.1155/2017/3548360

13. Nashif A.D., Jones D.I.G., Henderson J.P. Vibration Damping. John Wiley \& Sons, 1985. $480 \mathrm{p}$.

14. De Silva C.W. Vibration Damping, Control, and Design. 1st ed. CRC Press, 2007. 634 p.

15. Ünker F., Çuvalci O. Vibration control of a column using a gyroscope // Procedia - Social and Behavioral Sciences. Vol. 195. Pp. 2306-2315. 3 July 2015. DOI: 10.1016/j.sbspro.2015.06.182

16. William P.R. Theoretical and computational aeroelasticity. 1st edition. Crest Publishing, 2011.347 p.

17. Чернышев С.Л. Тенденции развития вычислительной механики для прочностного проектирования конструкций ЛА / С.Л. Чернышев, М.Ч. Зиченков, Ф.З. Ишмуратов, В.В. Чедрик // Чебышевский сборник. 2017. Т. 18, № 3 (63). С. 488-505. DOI: 10.22405/22268383-2017-18-3-488-505

18. Парафесь С.Г., Смыслов В.И. Проектирование конструкции и САУ БПЛА с учетом аэроупругости. Постановка и методы решения задачи. М.: Изд-во «Техносфера», 2018. $182 \mathrm{c.}$

19. Гарифуллин М.Ф. Числительные методы в расчетных и экспериментальных исследованиях нестационарных явлений аэроупругости. Кн. 1: Численные методы в расчетных исследованиях. М.: Наука, 2016. 350 с.

20. Wright J.R., Cooper J.E. Introduction to aircraft aeroelasticity and loads. 2nd ed. John Wiley \& Sons, 2015. 574 p.

\section{СВЕДЕНИЯ ОБ АВТОРАХ}

Овчинников Валерий Валерьевич, доктор технических наук, профессор, заведующий кафедрой основ физики Московского государственного технического университета имени Н.Э. Баумана, vvovchinnikov@bk.ru

Петров Юрий Владимирович доктор технических наук, профессор, заведующий кафедрой технической механики и инженерной графики МГТУ ГА, doctor561@rambler.ru

Поступила в редакцию

Принята в печать
20.03.2020

21.05.2020
Received

Accepted for publication
20.03.2020

21.05 .2020 